\title{
Factors That Influence the Use of Online Ticket Application (Case Study: Traveloka)
}

\author{
Akhmad Arfan ${ }^{1}$, Mirza $^{2}$ \\ ${ }^{1,2}$ Master of Management Faculty of Mercu Buana University, Jakarta, Indonesia
}

\begin{abstract}
This research was conducted to determine the perception of security, perceived usefulness, trust, repurchase intentions on traveloka.com. In addition, to find out which variable most influences the decision to repurchase intention.
\end{abstract}

The population in this study is citizens in Greater Jakarta and the number of samples used was 225 respondents. The sampling technique in this study is Non- Probability Sampling using accidental techniques, and then the results of data analysis are processed using SEM software.

These results show that the main factor which can increase repurchase intention for traveloka.com is consumer trust. It is very important for Traveloka management team to increase consumer trust by increasing usefulness and security feature in traveloka.com

Keywords:- Security Perception, Perception of Use, Trust and Repurchase Intention, Traveloka.

\section{INTRODUCTION}

The internet and the modern world are inseparable from each other, the internet was originally developed by the US in the mid- $19^{\text {th }}$ century, and used for military purposes only. At this time in developed countries, the internet is almost be the primary need. The services offered by the internet are even more complete, communicative and spoil consumers in the sense of internet access. ADSL (Asymmetric Digital Subscriber Line) technology in recent years has made the Internet a must-have for 24-hour internet access. In the early days, the use of the internet was limited to sending electronic mail (e-mail). However, along with the development of hardware and software that is very fast and rapid, the material delivered by the internet web is experiencing very fast development as well, where the material created is not limited to text only, but can also be in the form of images, sound, video, streaming, to those that are interactive, such as chatting, video conference, and so forth (Sumargono, 2011).

As for the history of the Internet in Indonesia itself, it began in the early 1990s. At that time the internet network in Indonesia was better known as the community network, where the spirit of cooperation, kinship and mutual cooperation was very warm and felt among the perpetrators. Although along with its development, the internet now feels more commercial and individual in some of its activities, especially those involving internet commerce (Gustino, 2011). The internet network is growing so rapidly accompanying the development of an increasingly sophisticated technology world. Most people now rely on technology to help their daily lives. With technology, modern society is no longer overwhelmed by the complicated works. Advanced technology and the internet have become an essential parts of everyday life. According to APJII 2018 data, it is known that the growth of internet users in Indonesia is quite rapid, which is where every year there is always a significant increase. To illustrate, the growth of Internet users in Indonesia can be seen in the graph below.

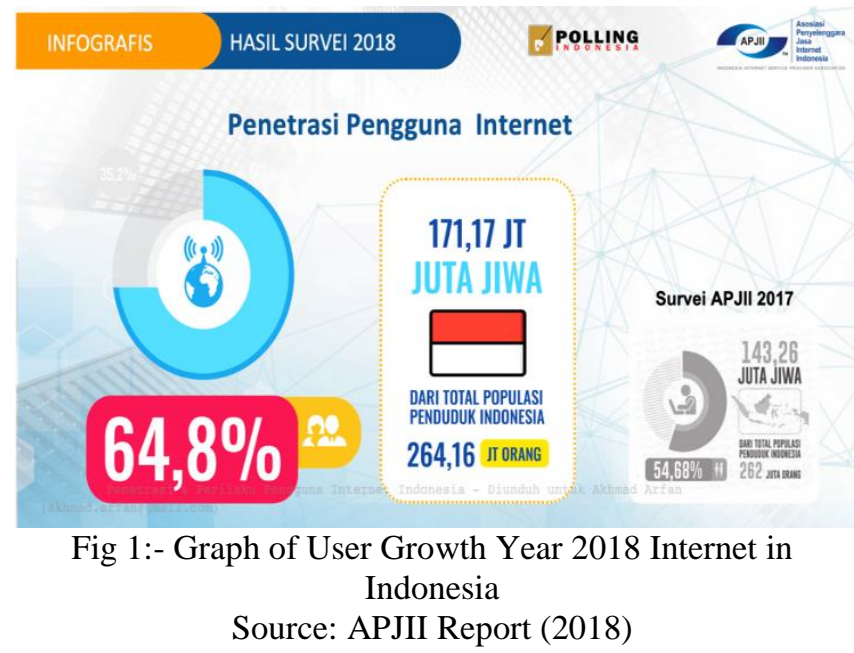

Based on the graph above, it can be seen that the growth of internet users was growing quite fast. Compared from 2017 to 2018, the increase was quite sharp, which in 2017 reached 143.26 millions inhabitants and the next year has surged, 171.17 millions. Given these numbers, it is no surprise that many business owners are using this as a new opportunity to expand their market shares.

Indonesian consumers love online shopping as increasing internet penetration in Indonesia consumers enjoy reading reviews of products or services and seeking detailed information on the products or services they need (nielsen.com, 2014). These facts can be concluded that Indonesian people are already adapting to the emergence of e-commerce and are becoming accustomed to shopping online. Thus finding and buying or doing online transactions for products or services is a common thing that people do. 
Online retailers are aware of the lack of face-to-face interaction with consumers and less reliable information, leading the online shopping to face more challenges than off-line shopping, including distrust, low switching cost, uncertainty, and rapid spread of word-of-mouth (Zhang et al., 2011a). It can be seen that consumers' interest to repurchase online (online repurchase intention) is a very important factor in e-commerce, and online retailing compete with each other to retain consumers and increase company profitability. Online repurchase intention is a source of profit for a company.

One of business player who sees the internet as a new market share in attracting consumers is the online travel agent business. In the beginning, this travel business was only done conventionally.

According to Top Brand Index data, Traveloka.com is one of the brands that get the Top Brand in 2017 in the field of online flight ticket booking and travel, in 2018 and 2019 Taveloka remains a Top Brand. But if we look at the table below there is a decrease in the presentation side every year, from $78.5 \%$ in 2017 to $30.0 \%$. Top Brand Index is the result of research on consumers. Research was conducted through a survey from Frontier Consulting Group in eleven major cities in Indonesia and used parameters measured based on top of mind share, top of market share, and top of commitment share.

TOP BRAND SITUS ONLINE BOOKING TIKET

PESAWAT DAN TRAVEL
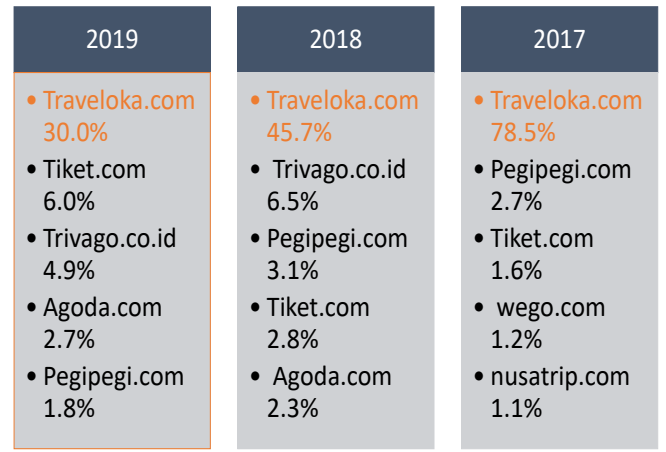

Fig 2:- Top Brand Index of Online Plane and Travel Booking Sites Source: topbrandaward.com (2020)

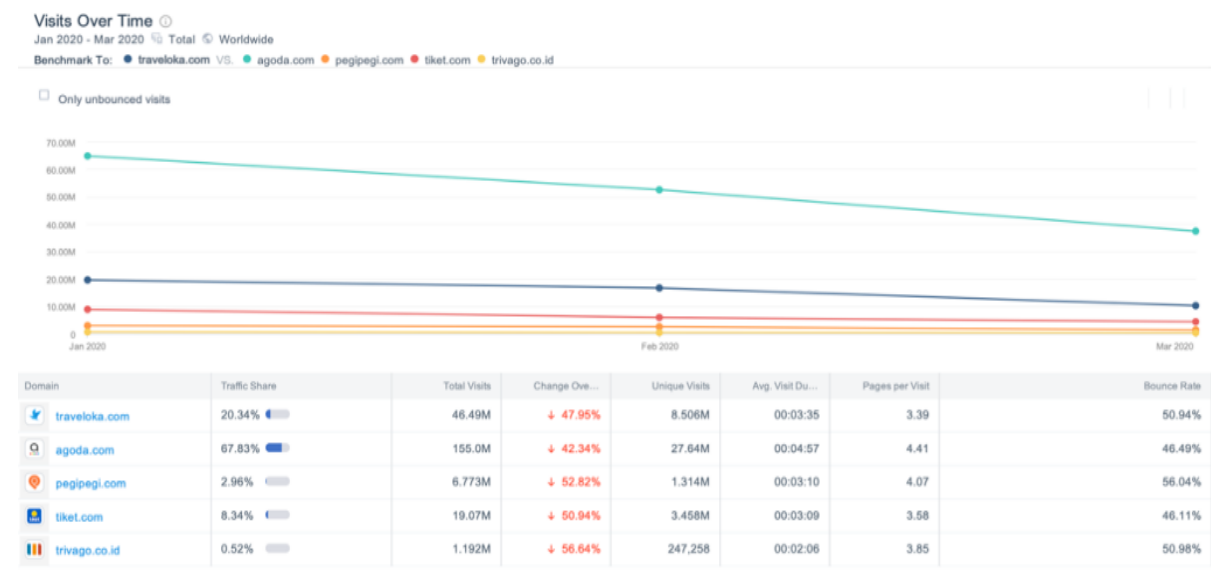

Fig 3:- Ticket Online Agent Visitors Site Data 2020

Source: similarweb.com (2020)

In 2020 traveloka.com can experience a decline in traffic, but in a stable condition, this is due to the COVID-19 pandemic. Which greatly affected the decline in the last 3 months and not only traveloka, but also with the other online tickets.

\section{$>$ Pre-Survey}

To find out which indicators are relevant to the study variables conducted on several respondents. According to Malhotra, N., \& Birks, D. (2017) respondents used in the Pre-Survey should be drawn from the population used in the actual survey. Therefore, the Pre Survey in this study was conducted for Traveloka.com app users with a range of 22 - 35 years who lived in Jabodetabek and had previously purchased a plane ticket through the Traveloka app. Consequently, the Pre-Survey in this study was done to 35 respondents. The purpose of this Pre-Survey is to find out some factors that are considered to affect Repurchase Intention and Satisfied. 
ISSN No:-2456-2165

\begin{tabular}{|c|c|c|c|c|c|c|}
\hline \multirow[t]{2}{*}{ No } & \multirow{2}{*}{$\begin{array}{l}\text { Factors that you should consider when you are transacting with the same online } \\
\text { travel agent }\end{array}$} & \multicolumn{5}{|c|}{ Ratings } \\
\hline & & STS & TS & $\mathrm{N}$ & $\mathrm{S}$ & SS \\
\hline 1 & The prices provided by traveloka.com are relatively competitive & 1 & 2 & 3 & 4 & 5 \\
\hline 2 & Interesting Ads and Promotions & 1 & 2 & 3 & 4 & 5 \\
\hline 3 & Trust in Travel Agent Online Sites & 1 & 2 & 3 & 4 & 5 \\
\hline 4 & Transaction Security (Order Systems and Processes) & 1 & 2 & 3 & 4 & 5 \\
\hline 5 & Travel Agent can be trusted in ticket bookings & 1 & 2 & 3 & 4 & 5 \\
\hline 6 & Online travel agent brand & 1 & 2 & 3 & 4 & 5 \\
\hline 7 & Loyalty and Points Program & 1 & 2 & 3 & 4 & 5 \\
\hline 8 & Recommendations from Friends & 1 & 2 & 3 & 4 & 5 \\
\hline 9 & Quality of service provided & 1 & 2 & 3 & 4 & 5 \\
\hline 10 & Use of brand ambassador & 1 & 2 & 3 & 4 & 5 \\
\hline
\end{tabular}

Table 1:- Factors Influencing Repurchase Intention and Satisfied on Traveloka.com Source: Researcher Survey (2020)

\begin{tabular}{|c|c|}
\hline Factor & Value \\
\hline Trust & 4.54 \\
\hline Security & 4.40 \\
\hline Perceived Usefulness & 4.34 \\
\hline Brand & 4.31 \\
\hline Service Quality & 4.06 \\
\hline Loyalty Program & 3.94 \\
\hline Price & 3.91 \\
\hline Advertisement and Promotion & 3.83 \\
\hline Recommendations & 3.69 \\
\hline Brand Ambassador & 3.49 \\
\hline
\end{tabular}

Tabel 2:- Pre-Survey Results

Source: Researcher Survey (2020)

Based on the results of questionnaire survey that out of 35 respondents using traveloka.com application, the trust factor of traveloka.com has the highest value with a value of 4.54, then service perception is ranked second with a value of 4.40 , followed by security in the third with a value of 4.34 and other factors is a brand with a value of 4.31 , and the service quality is 4.06 .

The author makes a diagram to show more clearly the factors that influence consumer buying interest, the diagram as follows:

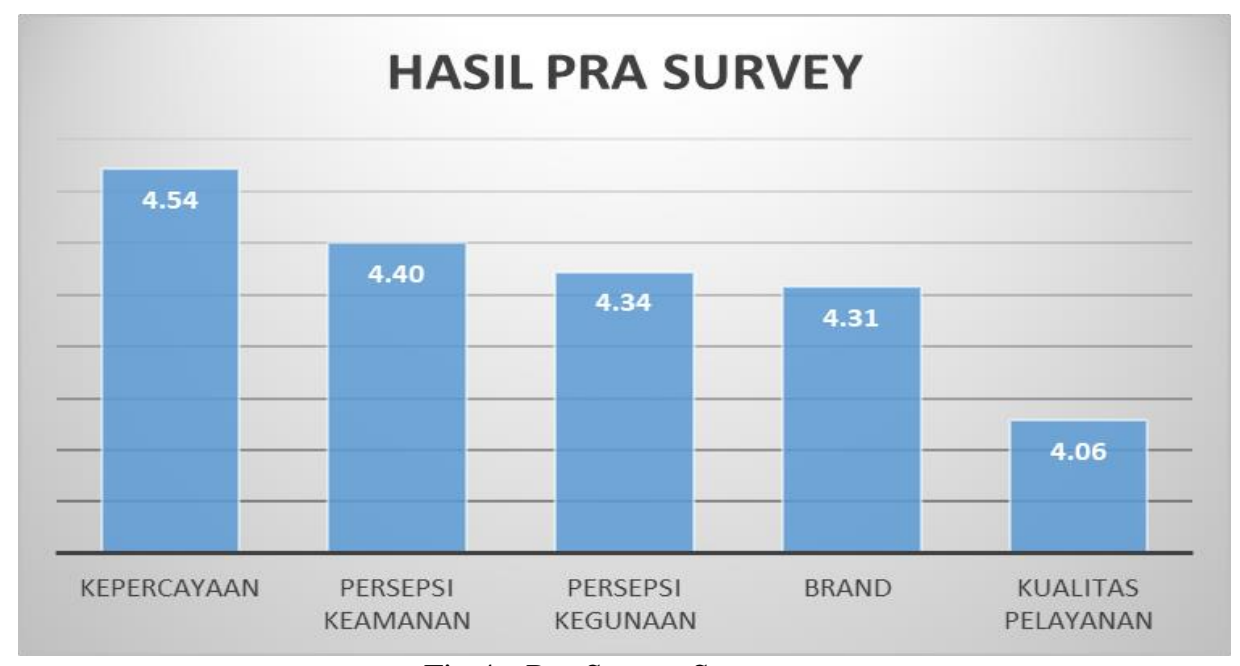

Fig 4:- Pre-Survey Summary

Source: Researcher Survey (2020) 
From Figure 4 it can be seen that the dominant factors which is influencing consumer repurchase interest are Trust, Consumer Usefulness, and Security on online travel agent sites. Having a good understanding of online repurchase intention in a business can develop effective and efficient strategies to retain existing customers to continue to buy back online. Therefore, it is very important for those who undergo online business to be aware of the factors that can influence and support consumers to make a repurchase.

Consumer trust in e-commerce as one of the factors that can influence and support the creation of an online repurchase intention to consumers. Consumer trust in ecommerce that specifically occurs at an online auction can also be referred to as an online trust. Roca et al (2009) defined when consumers feel comfortable interacting with a website, they tend to develop trust in the website, and trust is a key strategy for dealing with uncertainty and fearness. Consumers must have a sense of comfort that makes trust in an online site. Egger (2009) argued that sufficient online trust needs to be present when ordering online and when consumers provide financial information and other personal data when conducting financial transactions.

\section{THEORETICAL REVIEW}

\section{Security}

According to Park and Kim in Alwafi and Magnadi (2016: 4) security is defined as the ability of online stores to control and maintain the security of data transactions. Security perception is classified as an objective and subjective security problem. Objective security refers to the statement of security policy and technical protection, while subjective security refers to the overall security felt by consumers (Chellappa and Pavlou in Wijaya and Jasfar, 2014: 44).

Trust has been considered as a catalyst in various transactions between sellers and buyers in order that customer satisfaction can be realized as expected (Yousafzai, Pallister \& Foxall in Juniwati, 2015: 142).

\section{$>$ Perceived Usefulness}

Davis in Sianadewi et al (2017: 106) defines perceived usefulness with "the degree to which a person believes that using a particular system would enhance his or her job performance." In the context of online purchases, perceived usefulness is the level where consumers believe that they will feel certain benefits or benefits if they make a purchase at an online store. Perceived usefulness is defined as the extent to which a person believes that the use of a particular information system will improve its performance. From this definition it is known that the usefulness of perception is a belief about the decision-making process. If someone feels that the system is useful then he will use it. Conversely, if someone feels that the information system is less useful then he will not use it (Santoso, 2012: 4).

\section{Trust}

Trust is the foundation of business. A business transaction between two or more parties will occur if each of them trusts each other. This trust cannot just be recognized by other parties / business partners but must be built from scratch and can be proven. Trust has been considered as a catalyst in various transactions between sellers and buyers so that customer satisfaction can be realized as expected (Yousafzai, Pallister \& Foxall in Juniwati, 2015: 142). Consumer confidence in the internet at an online shop occurs because consumers are getting aroused by their needs and curiosity more and more in the search for information to get what they want. The main concern of marketers is the sources of information that become a reference for consumers and the strong influence of each source there is a purchase decision (Kotler and Keller. 2009: 235).

\section{$>$ Repurchase Intention}

Repurchase intention is post-purchase consumer actions. The occurrence of satisfaction and dissatisfaction with the purchase of the products will affect subsequent behavior. If the consumer is satisfied, a higher return will be displayed for the repurchase of the products (Kotler \& Keller, 2012). According to Simamora in Hamka (2010: 2) interest in buying products arises due to basic trust in products and a wide range of other factors, companies that can achieve and maintain differences will become companies above the average in the industry if the additional costs needed to be unique.

\section{FRAMEWORK}

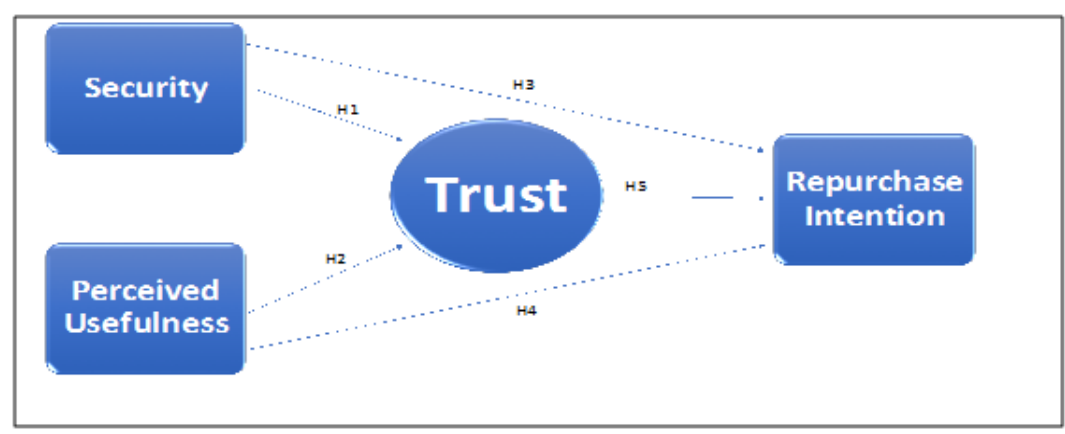

Fig 5:- Framework

Source: The data were processed by researchers (2020) 
H1: Security influences Consumer Trust.

H2: Perceived Usefulness influences Consumer Trust.

H3: Perceived Usefulness influences Repurchase Intention.

H4: Security influences Repurchase Intention.

H5: Consumer Trust influences Repurchase Intention.

\section{RESEARCH METHODS}

\section{Type of Research}

This study uses an explanatory research type with the aim of causality research, which is to look for explanations in causal relationships between variable relationships. In this study the hypothesis presented is the causality hypothesis which is used as a basis for analyzing the causal relationship of a variable that is between several independent variables $X$ that influence with one dependent variable Y which is affected (Hapzi Ali, 2013). This study uses a quantitative approach that is a way to gain knowledge or solve problems faced and carried out systematically and the data collected in the form of a series or collection of numbers.

\section{Population and Samples}

The sampling technique is done by the nonprobabilistic sampling method, namely purposive sampling.

Ferdinand followed by Sanusi (2011) explained in the Structural Equation Model (SEM) method, the ideal and representative number is $100-200$ depending on the number of parameters (indicator variables) that are estimated. The number of samples is 5-10 times the number of indicators. Then the number of samples to be taken for this study was 110 respondents from the calculation of $22 \times 5$. This is done to avoid data that is distorted and also following the estimation procedures that range from 100-200 respondents.

\section{Variable Measurement Scale}

In the questionnaire, the researchers used a Likert scale to measure the responses given by the respondents. According to Sugiyono (2012) Likert scale used to measure attitudes, opinions, and perceptions of a person or group of people on a social phenomenon that is happening, with scores range from 1 to 5 . The definition of Likert scale scores that are used can be seen in Table 3 as follows:

\begin{tabular}{|c|c|c|}
\hline Score & \multicolumn{2}{|c|}{ Likert Scale Score Definition } \\
\hline $\mathbf{5}$ & SS & Strongly Agree \\
\hline $\mathbf{4}$ & S & Agree \\
\hline $\mathbf{3}$ & CS & Neutral \\
\hline $\mathbf{2}$ & TS & Disagree \\
\hline $\mathbf{1}$ & STS & Strongly Disagree \\
\hline
\end{tabular}

Table 3:- Likert Scale

Source: Sugiyono (2012)

\section{Data Collection Techniques}

Data collection techniques are carried out through the following techniques: Questionnaire, Interview, Documentation Study.

\section{Data Analysis Techniques}

The analysis technique chosen in this study is crosssectional research with Structural Equation Modeling or SEM.

\section{RESEARCH RESULTS AND DISCUSSION}

\section{Results of Respondent Characteristics}

\begin{tabular}{|c|c|c|c|}
\hline \multicolumn{2}{|c|}{ Characteristics } & \multirow{2}{*}{$\begin{array}{c}\text { Number of Respondents } \\
8\end{array}$} & \multirow{2}{*}{$\begin{array}{c}\text { Percentage } \\
3,6 \%\end{array}$} \\
\hline \multirow{5}{*}{ Age } & $<20$ Old Years & & \\
\hline & 21 Old Years to 30 Old Years & 108 & $48,0 \%$ \\
\hline & 31 Old Years to 40 Old Years & 93 & $41,3 \%$ \\
\hline & 41 Old Years to 50 Old Years & 15 & $6,7 \%$ \\
\hline & 51 Old Years to 60 Old Years & 1 & $0,4 \%$ \\
\hline & Total & 225 & $100 \%$ \\
\hline \multirow{2}{*}{ Gender } & Men & 154 & $68,4 \%$ \\
\hline & Women & 71 & $31,6 \%$ \\
\hline & Total & 225 & $100 \%$ \\
\hline \multirow{4}{*}{ Education } & Junior High School & 1 & $0,4 \%$ \\
\hline & Senior High School & 30 & $13,3 \%$ \\
\hline & D3/Diploma & 12 & $5,3 \%$ \\
\hline & S1/Bachelor's Degree & 140 & $62,2 \%$ \\
\hline
\end{tabular}


ISSN No:-2456-2165

\begin{tabular}{|c|c|c|c|}
\hline & S2/Master's Degree & 42 & $18,7 \%$ \\
\hline & Total & 225 & $100 \%$ \\
\hline \multirow{9}{*}{ Occupation } & Senior High Schooler & 2 & $0,9 \%$ \\
\hline & College Student D3/S1/S2 & 31 & $13,8 \%$ \\
\hline & Housewife & 8 & $3,6 \%$ \\
\hline & Public Employee & 10 & $4,4 \%$ \\
\hline & Private Employee & 152 & $67,6 \%$ \\
\hline & Entrepreneur & 15 & $6,7 \%$ \\
\hline & Unemployment & 7 & $3,1 \%$ \\
\hline & Total & 225 & $100 \%$ \\
\hline & $<1$ Million & 23 & $10,2 \%$ \\
\hline \multirow{5}{*}{ Total Income } & 1 Million -5 Millions & 37 & $16,4 \%$ \\
\hline & 5 Millions - 10 Millions & 64 & $28,4 \%$ \\
\hline & 10 Millions - 15 Millions & 34 & $15,1 \%$ \\
\hline & $>15$ Millions & 67 & $29,8 \%$ \\
\hline & Total & 225 & $100 \%$ \\
\hline \multirow{7}{*}{ Frequency of Use } & Every Day & 1 & $0,4 \%$ \\
\hline & 1 Week 3 Times & 3 & $1,3 \%$ \\
\hline & 1 Week 2 Times & 3 & $1,3 \%$ \\
\hline & 1 Week 1 Time & 10 & $4,4 \%$ \\
\hline & 1 Month 1 Time & 195 & $86,7 \%$ \\
\hline & More than 1 Month & 13 & $5,8 \%$ \\
\hline & Total & 225 & $100 \%$ \\
\hline \multirow{5}{*}{ Expenditures for Tickets } & $<500$ Thousands & 51 & $22,7 \%$ \\
\hline & 500 Thousands - 1 Million & 89 & $39,6 \%$ \\
\hline & 1 Million - 5 Millions & 82 & $36,4 \%$ \\
\hline & $>5$ Millions & 3 & $1,3 \%$ \\
\hline & Total & 225 & 100 \\
\hline
\end{tabular}

Table 4:- Respondents Characteristics

Overall Model Match Evaluation Results

\begin{tabular}{|c|c|c|c|}
\hline Goodness of Fit Measure & Cut-off-Value & Test Results & Match Level \\
\hline \multicolumn{4}{|l|}{ Absolute Compatibility Test } \\
\hline P-value & $>0.05$ & 00.00 & Poor fit \\
\hline Root Mean Square Error of Approximation (RMSEA) & $\leq 0.08$ & 0.078 & Good fit \\
\hline Goodness of Fit Index (GFI) & $\geq 0.90$ & 0.98 & Good fit \\
\hline \multicolumn{4}{|l|}{ Incremental Compatibility Test } \\
\hline Adjusted Goodness of Fit Index (AGFI) & $\geq 0.90$ & 0.95 & Good fit \\
\hline Normed Fit Index (NFI) & $\geq 0.90$ & 0.95 & Good fit \\
\hline Tucker-Lewis Index atau Non-Normed Fit Index (TLI/NNFI) & $\geq 0.90$ & 0.97 & Good Fit \\
\hline
\end{tabular}

Table 5:- Overall Model Fit Test Results

Source: Results of Data Processing with Lisrel 8.8 (2020) 
Based on the results of the table above it can be seen that there is 1 GOF measurement that shows a poor match and 5 GOF measurements that show a good match. Hence, it can be concluded that the model is fit, so it can be continued for the next process.

Measurement Model Analysis Results

\begin{tabular}{|c|c|c|c|c|c|}
\hline \multirow{2}{*}{ Latent Variable } & \multirow{2}{*}{ Manifest Variable } & \multirow{2}{*}{ Indicators } & \multicolumn{2}{|c|}{ Start } & \multirow[t]{2}{*}{ Conclusion } \\
\hline & & & SLF & t-values & \\
\hline \multirow{4}{*}{$\begin{array}{l}\text { Security } \\
(X 1)\end{array}$} & $\sec 1$ & Ensure Data Safety & 0,87 & 16,8 & Valid \\
\hline & $\sec 2$ & Protect Financial Information & 0,82 & 14,81 & Valid \\
\hline & $\sec 3$ & Protect From Unauthorized & 0,87 & 16,1 & Valid \\
\hline & $\sec 4$ & Protect From Manipulation & 0,88 & 16,35 & Valid \\
\hline \multirow{5}{*}{$\begin{array}{c}\text { Perceived Usefulness } \\
(X 2)\end{array}$} & pu1 & Improve Performance & 0,82 & 14,86 & Valid \\
\hline & pu2 & Increase Productivity & 0,77 & 13,58 & Valid \\
\hline & pu3 & Easier to Search & 0,86 & 15,94 & Valid \\
\hline & pu4 & Enhance Effectiveness & 0,91 & 17,54 & Valid \\
\hline & pu5 & Useful & 0,89 & 16,97 & Valid \\
\hline \multirow{9}{*}{$\begin{array}{c}\text { Trust } \\
(Y 1)\end{array}$} & $\mathrm{t} 1$ & Fulfilment commitment & 0,62 & & Valid \\
\hline & $\mathrm{t} 2$ & Information sincere and honest & 0,7 & 8,87 & Valid \\
\hline & $\mathrm{t} 3$ & Promised Offered & 0,66 & 8,51 & Valid \\
\hline & $\mathrm{t} 4$ & Mutual Benefit & 0,56 & 7,35 & Valid \\
\hline & t5 & Care with Customer & 0,68 & 8,71 & Valid \\
\hline & t6 & Do Anything harm customer & 0,64 & 8,23 & Valid \\
\hline & $\mathrm{t} 7$ & Experience in product & 0,71 & 8,97 & Valid \\
\hline & t8 & Good Resource & 0,58 & 7,66 & Valid \\
\hline & t9 & Service and Product Adapted & 0,76 & 9,45 & Valid \\
\hline \multirow{4}{*}{$\begin{array}{c}\text { Repurchase Intention } \\
(Y 2)\end{array}$} & ri1 & Buying use website & 0,92 & & Valid \\
\hline & ri2 & Reuse to website for next purchase & 0,86 & 19,4 & Valid \\
\hline & ri3 & Intent Revisit in the future & 0,93 & 23,72 & Valid \\
\hline & ri4 & Revisit to transaction & 0,49 & 7,99 & Valid \\
\hline
\end{tabular}

Table 6:- Test Match Model Initial and After Elimination

Source: SEM Analysis Results Lisrel 8.80

Based on the results of the table above, where the SLF value and t-values in each of the observed variables (manifest) have SLF values above 0.5 and the $\mathrm{Z}$-value is above 1.96. Thereof it can be concluded that all observed variables have fulfilled the validity and significant requirements.

\begin{tabular}{|c|c|c|c|c|}
\hline Latent Variable & Manifest Variable & CR & VE & Conclusion \\
\hline Security (X1) & Sec1-Sec4 & 0,92 & 0,74 & Reliable \\
\hline Perceived Usefulness (X2) & Pu1-Pu5 & 0,93 & 0,73 & Reliable \\
\hline Trust (Y1) & T1-T9 & 0,87 & 0,44 & Quite Reliable \\
\hline Repurchase Intention (Y2) & Ri1-Ri4 & 0,89 & 0,67 & Reliable \\
\hline
\end{tabular}

Table 7:- Value of Construct Reliability (CR) and Variance Extracted (VE) 
Based on the table above, it appears that the value of construct reliability (CR) of each latent variable is above 0.7 , while the extracted variance (VE) value of each latent variable is also above 0.5 . There is only one Trust latent variable that has a VE value below 0.5 . Hence it can be concluded that the reliability of the measurement model is good (reliable).

\section{Structural Model Analysis Results}

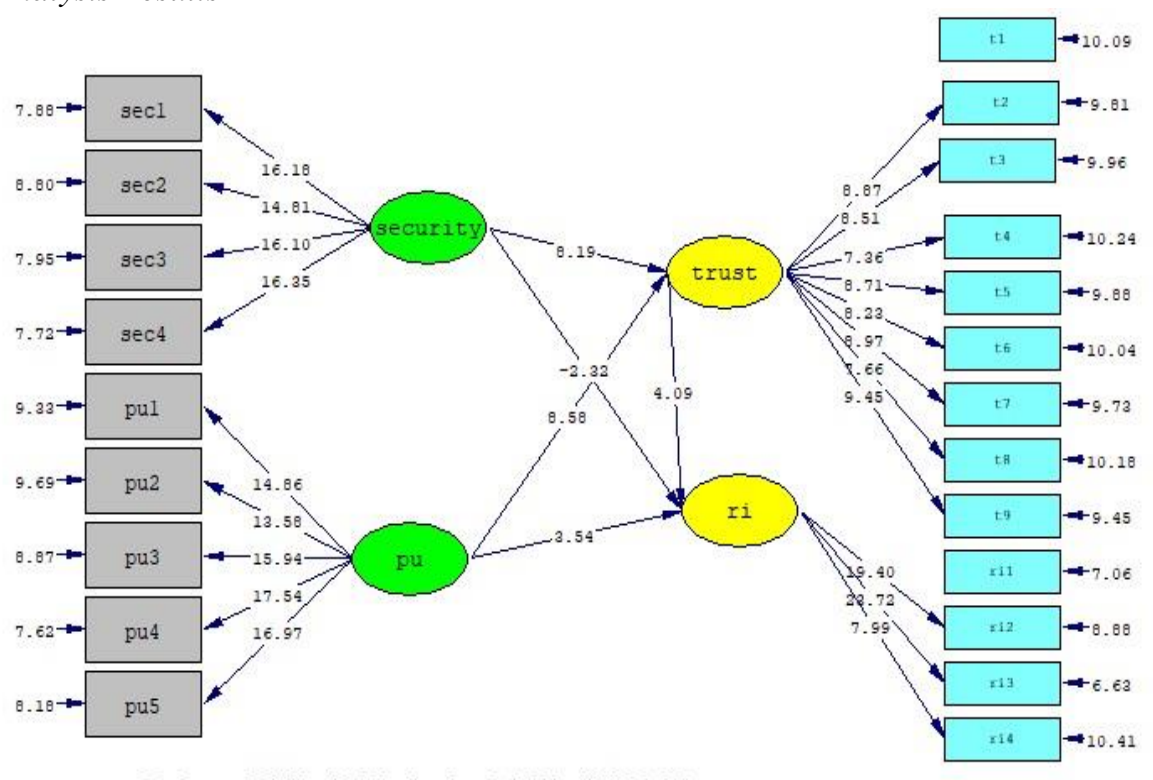

Chi-8quare $=554.43, d f=203, p-v a l u e=0.00000$, RMgEA $=0.088$

Fig 6:- Traveloka Structural Model Estimation Results (t-values) Source: SEM Analysis Results Lisrel 8.80

Based on the figure above, it appears that the $\mathrm{t}$-value of each relationship between latent variables has values above 1.96 . This can be interpreted that all research hypotheses are accepted.

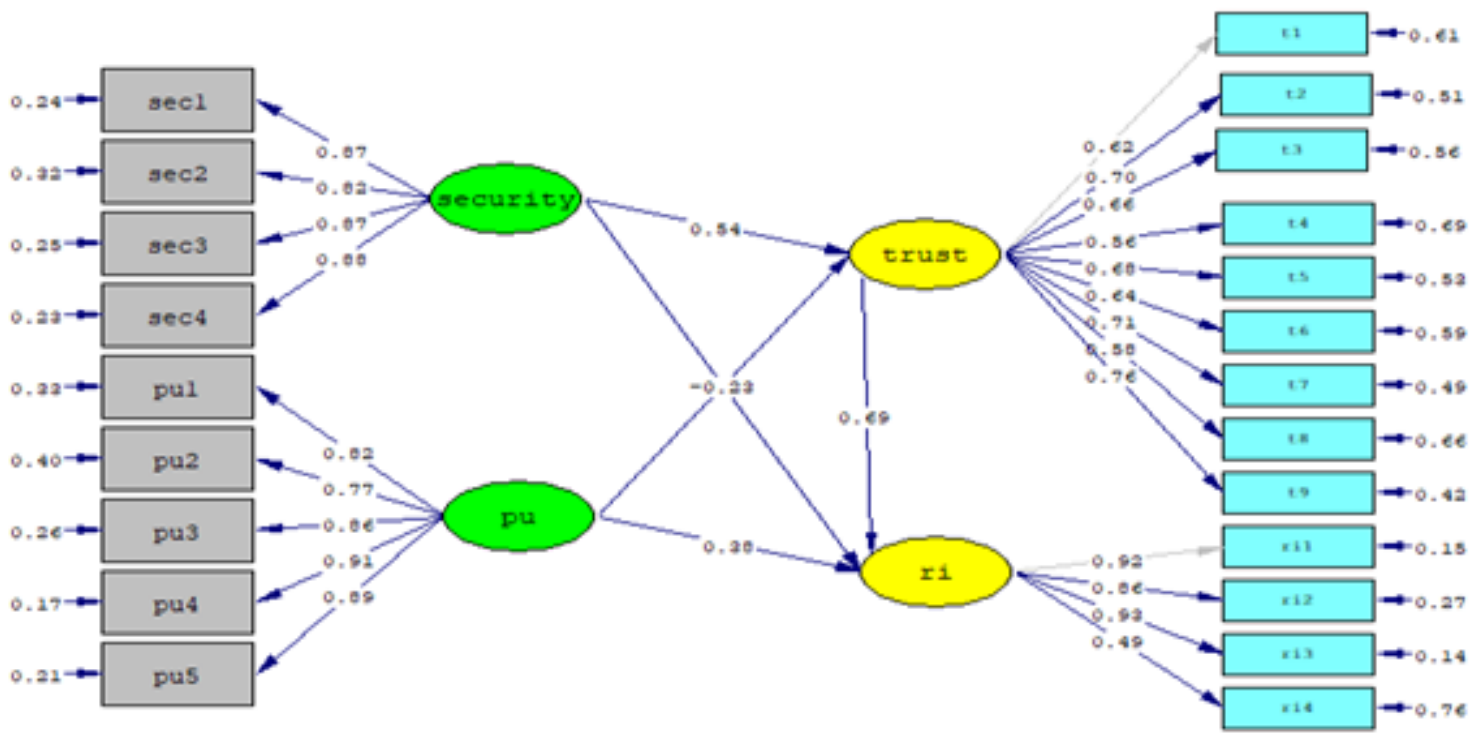

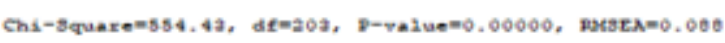

Fig 7:- Traveloka Structural Model Estimation Results (Standard Solution)

Source: SEM Analysis Results Lisrel 8.80

Based on the picture above, it can be concluded that the variable that has the greatest influence on repurchase intention in traveloka applications is the trust variable. This means that if consumers believe in traveloka services based on the results of previous transaction experience, then consumers will make an intention to use traveloka application services again. 
ISSN No:-2456-2165

\begin{tabular}{|c|c|c|c|c|}
\hline Hypothesis & Path & $\begin{array}{c}\text { Coefficient } \\
\text { Values }\end{array}$ & T - Values & Conclusion \\
\hline $\begin{array}{c}\text { Security influences Consumer } \\
\text { Trust. }\end{array}$ & Security $\rightarrow$ Trust & 0,54 & 8,19 & $\begin{array}{c}\text { Significant } \\
\text { (Hypothesis } 1 \\
\text { accepted) }\end{array}$ \\
\hline $\begin{array}{c}\text { Perceived Usefulness influences } \\
\text { Consumer Trust. }\end{array}$ & $\begin{array}{c}\text { Perceived Usefulness } \rightarrow \\
\text { Trust }\end{array}$ & 0,61 & 8,58 & $\begin{array}{c}\text { Significant } \\
\text { (Hypothesis } 2 \\
\text { accepted) }\end{array}$ \\
\hline $\begin{array}{c}\text { Perceived Usefulness influences } \\
\text { Repurchase Intention. }\end{array}$ & $\begin{array}{c}\text { Perceived Usefulness } \\
\text { Repurchase }\end{array}$ & 0,39 & 3,54 & $\begin{array}{c}\text { Significant } \\
\text { (Hypothesis } 3 \\
\text { accepted) }\end{array}$ \\
\hline $\begin{array}{c}\text { Security influences Repurchase } \\
\text { Intentions. }\end{array}$ & $\begin{array}{c}\text { Security } \rightarrow \text { Repurchase } \\
\text { Significant } \\
\text { (Hypothesis } 4 \\
\text { accepted) }\end{array}$ \\
\hline $\begin{array}{c}\text { Consumer Trust influences } \\
\text { Repurchase Intention. }\end{array}$ & Trust $\rightarrow$ Repurchase & $-0,23$ & $-2,34$ & $\begin{array}{c}\text { Significant } \\
\text { (Hypothesis } 5 \\
\text { accepted) }\end{array}$ \\
\hline
\end{tabular}

Table 8:- Evaluation of the Structural Model Coefficients and their Relation to the Research Hypothesis

Based on the results of the significance test, it can be concluded that: The t-value of the security influences consumer trust is 8.19 with a positive equation coefficient is 0.54 . Therefore t-value $(8.19)>1.96$ and the structural equation coefficient is positive. Consequently, it can be concluded that the security has a positive and significant effect on consumer trust (Hypothesis 1 is accepted). The better the level of security, the higher the level of consumer trust, and vice versa.

The t-value of the statistical effect of perceived usefulness on consumer trust is 8.58 with a positive equation coefficient is 0.61 . Therefore $t$-value $(8.58)>1.96$ and the structural equation coefficient positive sign can be concluded that the perceived usefulness has a positive and significant effect on consumer trust (Hypothesis 2 is accepted). If an application is easily used by consumers, the higher the consumer trust in traveloka applications and services.

The t-value of the statistical effect of perceived usefulness on repurchase is 3.54 with a positive equation coefficient is 0.39 . Since the t-value $(3.54)>0.39$ and the structural equation coefficient are positive, it can be concluded that the perceived usefulness has a positive and significant effect on repurchase interest (Hypothesis 3 is accepted). The better and easier to use the application according to respondents, the higher the interest in making repurchases.

The t-value of the statistical effect of security on repurchase is -2.34 with a negative equation coefficient of 0.23 . As t-value $(-2.34)<-0.23$ and the structural equation coefficient are negative, it is concluded that security has negative and significant effect on repurchase (Hypothesis 4 is accepted). If consumers perceive the security of a traveloka application is high, then the intention to repurchase traveloka services is getting lower. This negative influence has a meaning if security is not an important factor that is considered by consumers in repurchase traveloka services.
The t-value of the statistical effect of trust on repurchase is 4.09 with a positive equation coefficient of 0.69. Because t-value (4.09) > 1.96 and the structural equation coefficient are positive, it can be concluded that the perception of trust has a positive and significant effect on repurchase interest (Hypothesis 5 is accepted). The higher the level of consumer trust in traveloka services and applications, the higher the interest in repurchasing.

Based on the results of the above hypothesis test, it can be concluded that the five hypotheses are accepted, but there is 1 hypothesis that has a negative effect.

\section{CONCLUSION}

The conclusions obtained from the results of this study are as follows:

$>$ Security has a positive and significant effect on consumer trust. The better the level of security, the better the level of consumer trust for online travel agents.

$>$ Perceived usefulness has a positive and significant effect on consumer trust. The better the level of perceived usefulness, the better the level of consumer trust for online travel agents.

$>$ Perceived usefulness has a positive and significant effect on repurchase intention. The better the level of perceived usefulness, the better the level of consumer repurchase intention.

$>$ Security significantly influences repurchase intention. The better the level of security, the better the level of consumer repurchase intention.

$>$ Consumer trust has a positive and significant effect on repurchase intention. The better the level of consumer trust, the better the level of consumer repurchase intention. 


\section{REFERENCES}

[1]. Alwafi, F. dan Magnadi R.H. (2016). Pengaruh Persepsi Keamanan, Kemudahan Bertransaksi, Kepercayaan Terhadap Toko Dan Pengalaman Berbelanja Terhadap Minat Beli Secara Online Pada Situs Jual Beli Tokopedia.Com. DIPONEGORO JOURNAL OF MANAGEMENT. Vol.5. No.2.

[2]. Kotler, P; dan Amstrong, G. (2011) Manajemen Pemasaran. Jilid 2. Bumi Aksara. Jakarta

[3]. Roca, J. C., García, J. J., \& de la Vega, J. J. (2009). The importance of perceived trust, security and privacy in online trading systems. Information Management and Computer Security, 17(2), 96-113. https://doi.org/10.1108/09685220910963983

[4]. Sugiyono. (2011). Metode Penelitian Kombinasi (Mixed Methods) CV. Alfabeta. Bandung

[5]. Sumargono. (2011). Sejarah Perkembangan Internet Dan Kebutuhan Informasi Era Online Dalam Dunia Pendidikan. TEKNOLOGI: Jurnal Ilmiah Sistem Informasi. Vol.1. No.1.

[6]. Zhang, Y., Fang, Y., Wei, K. K., Ramsey, E., McCole, P., \& Chen, H. (2011). Repurchase intention in B2C e-commerce - A relationship quality perspective. Information and Management, 48(6), 192-200. https://doi.org/10.1016/j.im.2011.05.003 